\title{
XXXII. On the cause of a singular partial failure in a crop of turnips
}

\author{
Mr. Samuel Taylor
}

To cite this article: Mr. Samuel Taylor (1822) XXXII. On the cause of a singular partial failure in a crop of turnips, Philosophical Magazine Series 1, 60:293, 187-188, DOI: $10.1080 / 14786442208652816$

To link to this article: http://dx.doi.org/10.1080/14786442208652816

里 Published online: 29 Jul 2009.

Submit your article to this journal $₫$

Џ Article views: 2

Q View related articles $\sqsubset$ 
There is not a word more that calls for notice; the remainder of these interrogatories being awkwardly apologetic, rather than any thing else.

I have the honour to be, gentlemen,

Your much obliged and very obedient humble servant, Angust $9,1822$.

J. Murray.

XXXII. On the Cause of a singular partial Failure in a Crop of Turnips. By Mr. SaMuel Taylor, of Bungay.

To the Editors of the Philosophical Magazine and Journal.

Gentemenen, - As I find you do not exclude from your pages any information, however humble, on subjects connected with the study and practice of agriculture, allow me to lay before you a singular instance of partial failure in a field of turnips, which has recently come under my observation. This field is in the hands of my friend and neighbour Mr. Stamford, of Ditchingham, near this place. It may be necessary here to remark, that it is usual, in working our fallows intended for turnips, to cross-plough the land twice, in order to get the field perfectly level previous to stetching or ridging it up for the ensuing crop. Now the ridges or stetches of this field run north and south; but the failure in the turnip crop above mentioned extends across, not lengthrways of the ridges, and consequently in the direction of the rarting.

The following sketch may give a clearer idea than mere description can convey of my meaning, and of the present appearance of the field.

a \} Ploughed beginning of c $\}$ May: good healthy plants. d) Left unploughed from mid$d$ dle of May to beginning $d\}$ of June: a total failure d) of plant.

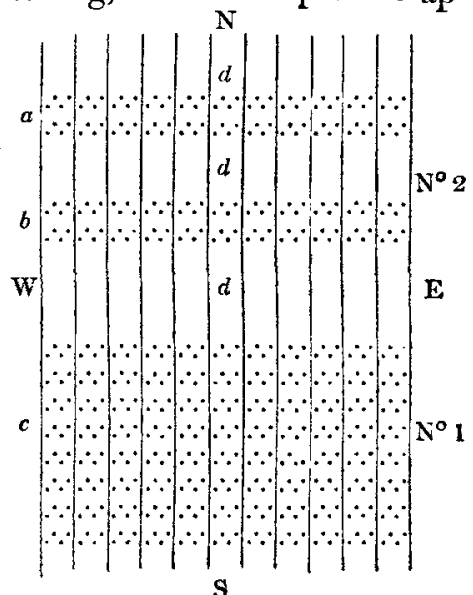

$\mathrm{s}$

Now what has occasioned this failure? and on what principle can we account for the narrow strips of good healthy plants 
across the field at $a$ and $b$, whilst those on each side of them have totally failed? An inquiry into the mode of culture will, perhaps, explain what at first sight appears rather mysterious. It seems that the field was roarted or cross-ploughed for the first time about the middle of April; the wheat stubble having been first turned in, as we call it, i.e. ploughed, before winter. It was again rearted the beginning of May. The whole field was stetched up for sowing about the beginning of June (being the fourth earth it had received); but in consequence of the long drought, it was not sown till the 12th of July. 'The seed (Swedish) was put on broadcast in one day. The plants came to the hoe in about a month afier; but for some time previous to hoeing, a partial deficiency of plant was noticed. Mr. S. was for a while at a loss to account for so singular and regular a failure, until reminded by his men of a circumstance which had escaped his recollection. The part of the field No. 1 lies lower, and is consequently more liable to injury from wet, than the upper part, No. 2. Having therefore finished crossploughing No. 1, he, knowing from the dryness of the soil that No. 2 could be ploughed at any time, took off his men and horses to some other work of more immediate importance; so that the whole of No. 2, except a fice furrors rohich had been ploughed (marked $a$ and $b$ ), lay for above a fortnight untilled. The deficiency of plant is therefore clearly attributable to this circumstance, because the whole of the remainder of the field, including the strips $a$ and $b$, produced good healthy plants : but then occurs the question, How could this suspension of operations for two or three weeks occasion such extraordinary effects? The answer appears to be this: The ground not being stirred during this interval, a multitude of grubs and wireworms were thereby suffered to hatch, which the plough would otherwise have destroyed; and these have doubtless eaten the plants. This idea appears to derive confirmation from the number of rooks which have ever since continued to alight ou the bare spots: on removing the surface earth of which, both grubs and wireworms are still found just buried beneath the mould.

Perhaps some of your readers better versed in these matters than I am, can give a more satisfactory solution of the above phænomenon. I merely state the facts, and endeavour to put the most reasonable interpretation on them in my power. If I am right, it would follow that it is not good to allow too long an interval between the spring ploughings; but I should be glad to know the opinion of entomologists on this subject.

In the mean time, I remain, gentlemen,

Your most obedient humble servant,

Bungay, Suffolk, Aug. 20, 1890.

Saming Taylok. 